\title{
New Hippocampal Neurons Mature Rapidly in Response to Ketamine But Are Not Required for Its Acute Antidepressant Effects on Neophagia in Rats $^{1,2,3}$
}

\author{
Amelie Soumier, Rayna M. Carter, Timothy J. Schoenfeld, and ${ }^{\circ}$ Heather A. Cameron
}

DOI:http://dx.doi.org/10.1523/ENEURO.0116-15.2016

Section on Neuroplasticity, National Institute of Mental Health, National Institutes of Health, Bethesda, Maryland 20892

\begin{abstract}
Virtually all antidepressant agents increase the birth of granule neurons in the adult dentate gyrus in rodents, providing a key basis for the neurogenesis hypothesis of antidepressant action. The novel antidepressant ketamine, however, shows antidepressant activity in humans within hours, far too rapid for a mechanism involving neuronal birth. Ketamine could potentially act more rapidly by enhancing maturation of new neurons born weeks earlier. To test this possibility, we assessed the effects of S-ketamine (S-(+)-ketamine hydrochloride) injection on maturation, as well as birth and survival, of new dentate gyrus granule neurons in rats, using the immediate-early gene zif268, proliferating cell nuclear antigen, and BrdU, respectively. We show that S-ketamine has rapid effects on new neurons, increasing the proportion of functionally mature young granule neurons within $2 \mathrm{~h}$. A single injection of S-ketamine also increased cell proliferation and functional maturation, and decreased depressive-like behavior, for at least 4 weeks in rats treated with long-term corticosterone administration (a depression model) and controls. However, the behavioral effects of S-ketamine on neophagia were unaffected by elimination of adult neurogenesis. Together, these results indicate that ketamine has surprisingly rapid and long-lasting effects on the recruitment of young neurons into hippocampal networks, but that ketamine has antidepressant-like effects that are independent of adult neurogenesis.
\end{abstract}

Key words: antidepressive agents; cell proliferation; dentate gyrus; mood disorders; neurogenesis; neuronal maturation

\section{Significance Statement}

Ketamine is a novel antidepressant agent that works very rapidly. Although ketamine acts as an antagonist of NMDA-type glutamate receptors, it is not clear how or where in the brain it acts to produce its antidepressant effects. This study demonstrates that ketamine has very rapid effects on the maturation of hippocampal neurons born in the adult brain, which have been linked to depression. However, behavioral experiments showed antidepressant-like effects of ketamine on neophagia that are independent of new neurons, in contrast to the effects of classic antidepressants on this behavior. Ketamine effects on new neurons should be considered as potential side effects of treatment and also point to a role for NMDA receptors in the normal maturation of new neurons. 


\section{Introduction}

Major depression is a complex and disabling psychiatric disorder that is commonly treated with monoaminergic agents, such as serotonin-selective reuptake inhibitors (SSRIs) or norepinephrine-selective reuptake inhibitors. These standard antidepressant agents have, in addition to limited therapeutic efficacy, delayed onset of action, requiring several weeks of treatment to produce clinical improvement (Browne and Lucki, 2013; Abdallah et al., 2015; ladarola et al., 2015). These limitations point to the need for more effective and faster-acting antidepressant treatments.

Beyond the monoaminergic system, accumulating evidence supports a role for glutamatergic transmission in depression. Abnormalities in glutamate levels in plasma and brain tissue, as well as alteration in glutamate (AMPA, kainate, NMDA) receptor function have been reported in depressed patients (Sanacora et al., 2008). Evidence suggests that adaptive changes in NMDA receptor expression and function may even represent a final common pathway for monoaminergic antidepressants (Skolnick et al., 1996, 2009). Supporting the idea that NMDA receptors represent promising antidepressant targets, several clinical studies have reported an antidepressant response to a single low-dose infusion of ketamine, a noncompetitive NMDA receptor antagonist (Abdallah et al., 2015; ladarola et al., 2015). Remarkably, antidepressant activity is observed in depressed patients resistant to prior treatments, begins in $<4 \mathrm{~h}$, and is relatively sustained, lasting at least 1-2 weeks (Abdallah et al., 2015; ladarola et al., 2015). Antidepressant effects of ketamine at subanesthetic doses have also been reported (Browne and Lucki, 2013) in rodent models of antidepressant efficacy, such as the forced swim and tail suspension tests. Preclinical studies (Browne and Lucki, 2013; Duman, 2014) suggest that ketamine may exert its antidepressant activity through alterations in AMPA receptors, BDNF, mammalian target of rapamycin, and glycogen synthase kinase-3, and the formation of new dendritic spines and synapses in the prefrontal cortex. However, other evidence points to a role for the hippocampus in the antidepressant effects of ketamine (Kavalali and Monteggia, 2015).

A key feature of the hippocampus is the ongoing production of granule neurons in the dentate gyrus through-

Received September 25, 2015; accepted February 26, 2016; First published March 23, 2016.

${ }^{1}$ The authors declare no competing financial interests.

${ }^{2}$ Author Contributions: A.S., R.M.C., and H.A.C. designed research; A.S., R.M.C., and T.J.S. performed research; A.S., R.M.C., T.J.S., and H.A.C. analyzed data; A.S., R.M.C., and H.A.C. wrote the paper.

${ }^{3}$ This work was supported by the Intramural Program of the National Institutes of Health, National Institute of Mental Health (Grant ZIAMH002784 to H.A.C).

Correspondence should be addressed to Heather A. Cameron, NIH, 35 Lincoln Drive, MSC 3718, Bethesda, MD 20892-3718. E-mail: heathercameron@ mail.nih.gov.

DOI:http://dx.doi.org/10.1523/ENEURO.0116-15.2016

Copyright (C) 2016 Soumier et al.

This is an open-access article distributed under the terms of the Creative Commons Attribution 4.0 International, which permits unrestricted use, distribution and reproduction in any medium provided that the original work is properly attributed. out life. The now well known "neurogenesis hypothesis" of antidepressant action has linked adult neurogenesis to mood disorders and their treatment (Duman et al., 2001; Warner-Schmidt and Duman, 2006). Six classes of monoaminergic antidepressants all increase the proliferation of granule cell precursors (Duman, 2004). Importantly, the delayed onset of antidepressant action parallels the time course of changes in neurogenesis. Although SSRIs immediately change extracellular levels of serotonin, several weeks of SSRI treatment are required to improve clinical symptoms in humans or to increase neurogenesis in animals (Malberg et al., 2000; Warner-Schmidt and Duman, 2006). Even if antidepressants were to rapidly increase cell proliferation, the additional new neurons would likely not contribute to behavior for several weeks after maturation and functional integration into the local hippocampal network (Piatti et al., 2006; Snyder et al., 2009b). This maturation delay suggests that the rapid behavioral effects of ketamine treatment are not due to the birth of new neurons.

Acceleration of neuronal maturation, a much later stage in the neurogenic process, may represent an important target for novel rapidly acting antidepressants. Previous studies have found that some antidepressants accelerate maturation after long-term treatment. Agomelatine, a novel antidepressant with mixed MT1/MT2 melatonin receptor agonist and $5-\mathrm{HT}_{2 \mathrm{C}}$ receptor antagonist properties, accelerates the maturation of young granule cells after $8 \mathrm{~d}$ of treatment (Soumier et al., 2009). Long-term treatment with the SSRI fluoxetine also facilitates the functional maturation of newly generated immature neurons after $21 \mathrm{~d}$, but not after $5 \mathrm{~d}$, of treatment, paralleling its effects on behavior (Wang et al., 2008). One of the fastest and most effective antidepressant treatments is electroconvulsive therapy (Warner-Schmidt and Duman, 2006); electroconvulsive seizures also stimulate dendritic outgrowth and maturation (Overstreet-Wadiche et al., 2006). Together, these studies suggest that the acceleration of hippocampal granule cell maturation could produce antidepressant effects. Therefore, we hypothesized that ketamine might rapidly enhance neuronal maturation to immediately increase the pool of functional young neurons in the hippocampus and that this increase could reduce depressive-like behaviors.

We assessed the rapid and sustained effects of Sketamine (S-(+)-ketamine hydrochloride, Sigma-Aldrich), an enantiomer of ketamine with robust effects and possibly fewer side effects (Mathew et al., 2012), in rodent behavioral tests that normally require long-term antidepressant treatment. We then determined the short-term effects of S-ketamine on the functional maturation of young neurons and the long-term effects of S-ketamine on granule cell birth, maturation, and survival. Finally, we tested the role of new neurons in the antidepressant-like action of ketamine on novelty-suppressed feeding (NSF).

\section{Materials and Methods}

\section{Animals}

For most experiments, adult (8-week-old) male LongEvans rats were ordered from a vendor (Charles River 
Laboratories) and pair housed under a standard $12 \mathrm{~h}$ light/dark cycle with free access to food and water for at least 1 week prior to the start of experiments. For testing the role of neurogenesis in NSF behavior, rats expressing herpes simples virus-thymidine kinase (HSV-TK rats) under the GFAP promoter (GFAP-TK rats) were generated on a Long-Evans background, using a construct previously used to make transgenic mice (Snyder et al., 2011). Male offspring were genotyped by PCR after weaning, and wild-type and transgenic littermates were randomly pair housed under a standard $12 \mathrm{~h}$ light/dark cycle for the duration of the experiment. All animal procedures were performed in accordance with the Institute of Laboratory Animal Research guidelines and were approved by the Animal Care and Use Committee of the National Institute of Mental Health.

\section{Drug treatments}

Experiment 1: behavioral effects of S-ketamine

Experiment 1a: novelty-suppressed feeding

Rats were deprived of food for $24 \mathrm{~h}$. S-ketamine at one of three doses $(2.5,5$, or $10 \mathrm{mg} / \mathrm{kg}$, all $2 \mathrm{ml} / \mathrm{kg}$ in $0.9 \%$ saline, i.p.) or saline was injected $1 \mathrm{~h}$ prior to testing. The highest dose used here, $10 \mathrm{mg} / \mathrm{kg}$, is $7.5-10 \times$ lower than anesthetic doses in rats; racemic mixtures at this dose produce antidepressant-like effects without altering spontaneous locomotor activity (Hunt et al., 2006; Wilson et al., 2007; Garcia et al., 2008; Engin et al., 2009; Li et al., 2010). One hour later, animals were placed in a brightly illuminated opaque Plexiglas box $(50 \times 50 \times 40 \mathrm{~cm})$ with six pellets of regular chow in the center. Behavior was video recorded from above for $10 \mathrm{~min}$, and latency to feed was determined from the recordings.

Experiment 1b: forced swim test

Rats were individually placed in a 50-cm-high clear cylinder containing water $\left(23 \pm 1^{\circ} \mathrm{C}, 30 \mathrm{~cm}\right.$ depth) for 15 min. One day later, rats were placed in the water again for a $5 \mathrm{~min}$ test. Each rat received three injections of S-ketamine (10 mg/kg, i.p.; Sigma-Aldrich), fluoxetine (10 $\mathrm{mg} / \mathrm{kg}$, i.p.; Sigma-Aldrich), or saline, $24 \mathrm{~h}, 4 \mathrm{~h}$, and 30 min prior to the test session (Porsolt et al., 2001). To assess the long-term effects, rats were placed in water again for $5 \mathrm{~min}$ at $21 \mathrm{~d}$ after drug injection. Swim sessions were video recorded from the side, and immobility, swimming, and climbing behaviors were scored at the end of each $5 \mathrm{~s}$ period from the recordings (Cryan et al., 2005).

\section{Experiment 2: short-term effects of S-ketamine}

Experiment 2a: effects $16 \mathrm{~h}$ after S-ketamine

Rats were injected with bromodeoxyuridine (BrdU; 200 $\mathrm{mg} / \mathrm{kg}$, i.p.; $10 \mathrm{mg} / \mathrm{ml}$ in saline with $0.007 \mathrm{~N} \mathrm{NaOH}$ ) to identify young granule cells for maturation and survival analyses. Beginning $2 \mathrm{~d}$ after BrdU injection (Day 2), rats were injected daily with saline for $14 \mathrm{~d}$ to match the daily injections used for long-term treatment in Experiment 3. On Day 16, rats were given a single injection of either S-ketamine (10 mg/kg, i.p.; Sigma-Aldrich) or saline. Sixteen hours later (Day 17), they were injected with kainic acid (15 mg/kg, i.p.; Tocris Bioscience) to drive immediate-early gene (IEG) expression in synaptically integrated granule cells (Snyder et al., 2009a,b). Sodium pentobarbital (50 mg/kg, i.p.; Ovation Pharmaceuticals) was given to stop seizures 30 min after the onset of stage 5 seizure activity. Rats were perfused $90 \mathrm{~min}$ after the onset of stage 5 seizure onset.

Experiment 2b: effects of S-ketamine in 7-d-old cells

Rats were treated exactly as above in Experiment 2a, except that ketamine was injected on Day 7 after BrdU injection, and no saline injections were given on the intervening days.

Experiment 2c: effects $2 h$ after S-ketamine

Rats were treated exactly as above in Experiment 2a, except that ketamine was injected on Day 14 after BrdU injection, no saline injections were given on the intervening days, and kainic acid was injected $2 \mathrm{~h}$ after saline or ketamine (also on Day 14).

Experiment 3: effects of long-term S-ketamine treatment

Rats were injected with BrdU as described above. Beginning on Day 2 after BrdU injection, rats were injected daily with S-ketamine (10 mg/ml, i.p.; Sigma-Aldrich) or saline. After 14 or $21 \mathrm{~d}$ of daily ketamine injection, rats were injected with kainic acid followed by sodium pentobarbital, as described above, and were perfused $90 \mathrm{~min}$ after the onset of stage 5 seizure onset.

Experiment 4: sustained effects of ketamine in a depression model

Experiment 4a: sucrose preference test and survival effects

Rats were injected with BrdU as described above. On Day 2 after BrdU injection, rats were injected once with either S-ketamine (10 mg/kg, i.p.; Sigma-Aldrich) or saline and then were given corticosterone (CORT) in their drinking water $(400 \mu \mathrm{g} / \mathrm{ml}$ in $2.5 \%$ ethanol/water, $\mathrm{v} / \mathrm{v}$, equivalent to $40 \mathrm{mg} / \mathrm{kg} / \mathrm{d}$; Sigma-Aldrich) to produce a depression-like state (Sterner and Kalynchuk, 2010). Control rats drank $2.5 \%$ ethanol/water. On Day 30, corticosterone and ethanol were removed from the drinking water, and rats were given a sucrose solution $(1 \%$ in drinking water; Sigma-Aldrich) in one bottle in addition to normal drinking water for a $48 \mathrm{~h}$ habituation period. The location of the sucrose bottles (left/right) was balanced across animals and was alternated after $24 \mathrm{~h}$. After $4 \mathrm{~h}$ of water deprivation at the beginning of dark phase, rats were given a $1 \mathrm{~h}$ free choice test with two identical bottles, one filled with the sucrose solution and the other with water. Sucrose preference was calculated as the volume of sucrose solution over total fluid volume consumed. Rats were perfused on Day 32, just after sucrose preference testing.

Experiment 4b: proliferation and maturation effects

Rats were treated as in Experiment $4 a$ above, except that BrdU was injected $16 \mathrm{~d}$ after corticosterone was added to the drinking water; there was no behavior testing; and, after $32 \mathrm{~d}$ of corticosterone treatment, rats were injected with kainic acid followed by sodium pentobarbital, as described above, and were perfused 90 min after the onset of stage 5 seizure onset.

\section{Experiment 5: effects of S-ketamine on behavior in the absence of new neurons}

Beginning at 8 weeks of age, GFAP-TK rats and wildtype littermates were given valganciclovir to eliminate 
Table 1: Statistical table

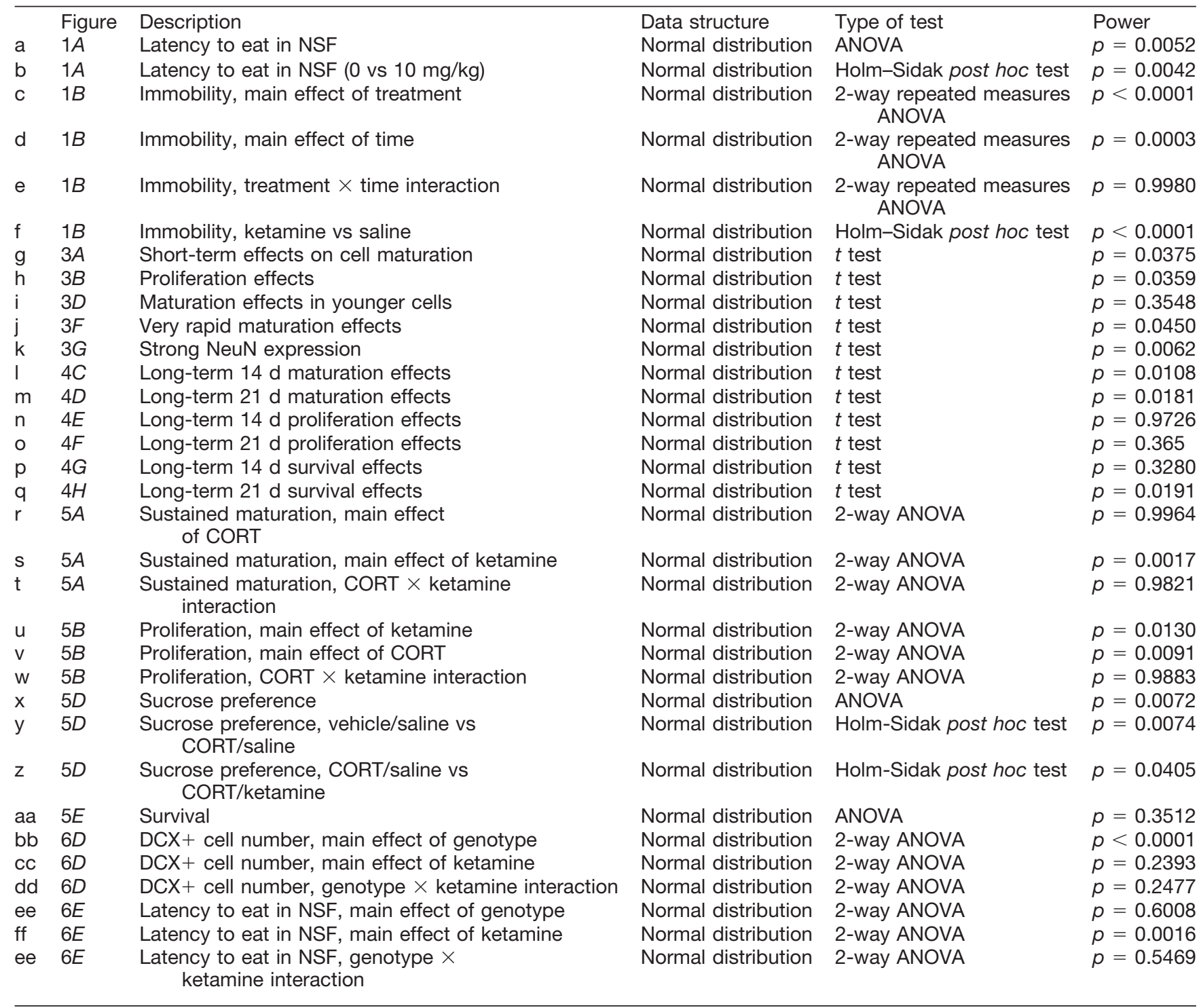

adult neurogenesis $(100 \mathrm{mg} / \mathrm{kg} /$ week, p.o., for 2 weeks, then $20 \mathrm{mg} / \mathrm{kg} /$ week for 6 weeks). After 8 weeks of valganciclovir treatment, rats were tested for noveltysuppressed feeding behavior, as described above. Rats were deprived of food for $24 \mathrm{~h}$ prior to testing. One hour prior to testing, rats were injected with saline or S-ketamine (10 mg/kg, i.p.; a gift from Irv Wainer, National Institute on Aging, Bethesda, MD). For testing, animals were placed in a brightly illuminated opaque Plexiglas box $(50 \times 50 \times 40 \mathrm{~cm})$ with six pellets of regular chow in the center. Behavior was video recorded from above for 10 $\mathrm{min}$, and the latency to feed was determined from recordings.

\section{Histological procedures and analysis}

Rats were perfused with $4 \%$ paraformaldehyde, and brains were sectioned at $40 \mu \mathrm{m}$ throughout the entire hippocampus. Complete series of sections were enzymatically immunostained for BrdU or proliferating cell nuclear antigen (PCNA), or were fluorescently immunostained for doublecortin (DCX) or BrdU and zif268 combined, using Alexa Fluor dye-conjugated secondary antibodies. zif268 is a synaptic activity-dependent immediate-early gene that is a reliable marker of the maturity of adult-born neurons (Jones et al., 2001; Snyder et al., 2009a,b; Jungenitz et al., 2014). BrdU-labeled (+), $\mathrm{PCNA}^{+}$, and $\mathrm{DCX}^{+}$cells in the granule cell layer and subgranular zone were counted stereologically, using a $40 \times$ objective, on 1:12 series of sections through the entire dentate gyrus. Cell counts were multiplied by 12 to estimate the total number in each rat. To quantify IEG expression, $25 \mathrm{BrdU}^{+}$cells per hemisphere from the dorsal dentate gyrus were analyzed for colabeling of zif268 and $\mathrm{NeuN}^{+}$using a $63 \times$ objective on a confocal microscope. Statistical analyses were performed using twoway ANOVA with Bonferroni post hoc tests, one-way ANOVA followed by the Dunnett's post hoc test, or Student's $t$ test as appropriate (Table 1). 
A
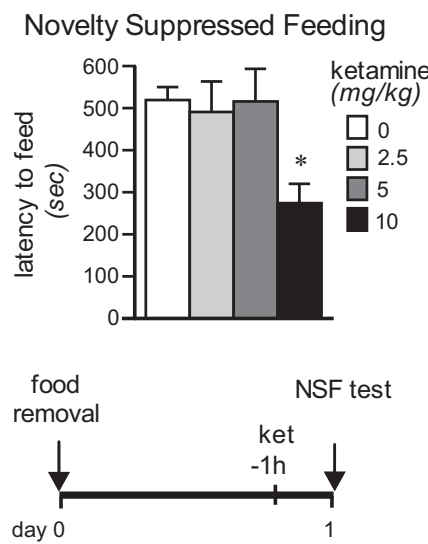

B

Repeated Forced Swim Test

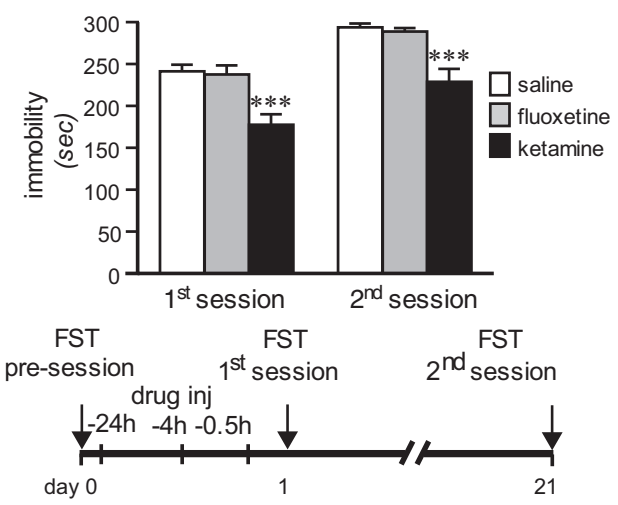

Figure 1. Rapid and sustained behavioral effects of S-ketamine. $\boldsymbol{A}$, Short-term S-ketamine (ket) treatment reduced the latency to eat in the novelty-suppressed feeding test (one-way ANOVA, $F_{(3,14)}=6.61, p=0.005 ; * \mathrm{Holm}-\mathrm{Sidak}$ test, $10 \mathrm{mg} / \mathrm{ml} \mathrm{vs}$ saline, $p=0.004$ ). $\boldsymbol{B}$, In the repeated forced swim test, short-term administration of S-ketamine reduced the time spent immobile immediately and 21 d later, while fluoxetine had no effect (two-way repeated-measures ANOVA; treatment effect: $F_{(2,9)}=31.65, p=0.0001$; time effect: $F_{(1,9)}=31.47, p=0.0003$; treatment $\times$ time interaction: $F_{(2,9)}=0.002, p=0.99 ; * * * p<0.001$ vs saline in post hoc test). All bars represent mean \pm standard error of the mean $(\mathrm{SEM})$.

\section{Results}

\section{Rapid and prolonged effects of ketamine on behavior}

The short- and long-term behavioral effects of S-ketamine in rats were examined in three tests. The NSF test, which is sensitive to long-term but not to short-term monoaminergic antidepressant treatment (Bodnoff et al., 1988), was used to assess the shortterm effects of ketamine at three different doses. The injection of $10 \mathrm{mg} / \mathrm{kg}$ ketamine $1 \mathrm{~h}$ prior to testing significantly reduced the latency to feed in the novel environment by $47 \%$ (one-way ANOVA, $F_{(3,14)}=6.61, p$ $=0.005 ; *$ Holm-Sidak test, $10 \mathrm{mg} / \mathrm{ml}$ vs saline, $p=$ 0.004 ; Fig. $1 A$ ), as previously observed with the racemic mixture (Li et al., 2010; Carrier and Kabbaj, 2013). Lower doses of 2.5 and $5 \mathrm{mg} / \mathrm{kg}$ had no effect, in contrast to what has been reported using the $5 \mathrm{mg} / \mathrm{kg}$ racemic mixture (Carrier and Kabbaj, 2013).

The forced swim test (FST) is used classically to detect antidepressant activity in rodents following short-term treatment (Porsolt et al., 2001). Repeated FST, which can detect behavioral changes following long-term treatment with low doses of classic antidepressants (Cryan et al., 2005), was used to assess the sustained antidepressant effect of ketamine (Fig. 1B). Short-term administration of ketamine $(10 \mathrm{mg} / \mathrm{kg}$, i.p.; $24 \mathrm{~h}, 4 \mathrm{~h}$, and $30 \mathrm{~min}$ prior to testing) significantly decreased immobility time by $30 \%$ in the first test and by $20 \% 21 \mathrm{~d}$ later (main effect of treatment: $F_{(2,9)}=31.65, p=0.0001$; main effect of time: $F_{(1,9)}$ $=31.47, p=0.0003$; treatment $\times$ time interaction: $F_{(2,9)}=$ $0.002, p=0.99$; ketamine vs saline: $p=0.0007$, first session; $p=0.0006$, second session). Treatment with the typical SSRI fluoxetine, at a dose showing long-term but not short-term effects in previous studies (Porsolt et al., 2001; Cryan et al., 2005), produced no effect in either session. These results indicate that low-dose ketamine, unlike fluoxetine, produces antidepressant-like effects that begin within $1 \mathrm{~d}$ and last at least 3 weeks, extending the time course previously observed in mice (Maeng et al., 2008).

\section{Ketamine rapidly accelerates functional maturation of new neurons in the dentate gyrus}

Kainate induced strong expression of zif268 throughout the granule cell layer in both groups (Fig. $2 A$ ). In control rats (Fig. $3 A$ ), $32 \%$ of the 16 -d-old neurons expressed zif268 in response to kainate activation, consistent with expectations for rat granule neurons at this time point (Snyder et al., 2009b). In ketamine-treated rats, the proportion of $\mathrm{BrdU}^{+} / \mathrm{NeuN}^{+}$cells labeled with zif268 was $67 \%$ higher ( $t$ test, $t_{(4)}=3.065, p=0.0375$; Fig. $3 A$ ), suggesting a rapid increase in the synaptic integration of 2-week-old granule cells. The 50 min half-life of ketamine in the rat brain (Mathew et al., 2012) is short relative to the $16 \mathrm{~h}$ post-ketamine administration delay in this experiment, arguing against any direct interaction between ketamine and kainate.

Increased granule cell precursor proliferation is a common feature of antidepressant treatments (Duman et al., 2001) and could play a role in long-term behavioral effects of ketamine. Mitotic cells were assayed $16 \mathrm{~h}$ after ketamine injection using the endogenous marker PCNA (Fig. $2 B$ ). Short-term administration of ketamine significantly increased the number of $\mathrm{PCNA}^{+}$cells located in the subgranular zone by $25 \%\left(t\right.$ test, $t_{(10)}=2.42, p=0.0359$; Fig. $3 B$ ), which is consistent with the increased cell proliferation produced by other NMDA receptor antagonists (Cameron et al., 1995; Nacher et al., 2001; Nacher and McEwen, 2006).

To test the maturation effects in younger cells, the experiment was repeated by administering BrdU only $7 \mathrm{~d}$ prior to ketamine injection (Fig. 3E). There was no effect of 

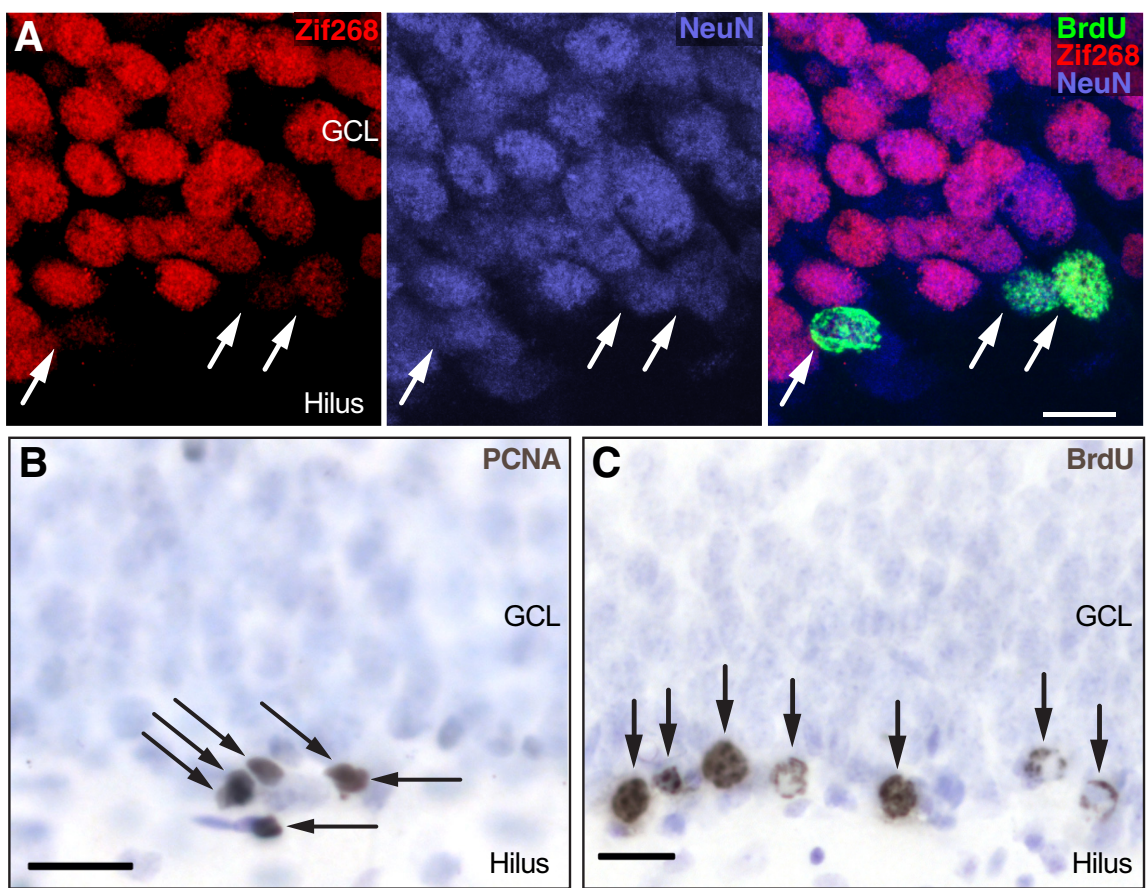

Figure 2. Examples of immunohistochemical markers. $\boldsymbol{A}$, After kainate injection, all mature granule neurons and some BrdU-labeled 16 -d-old $\mathrm{NeuN}^{+}$neurons expressed zif268, indicating synaptic activation. GCL, granule cell layer $\boldsymbol{B}$, Dividing cells (arrows) were identified using PCNA immunohistochemistry. C, Cells surviving 2-3 weeks (arrows) were identified with BrdU immunohistochemistry (gray-brown); immunonegative cells were stained with blue-purple counterstain.

ketamine on zif268 expression in these 7-d-old cells ( $t$ test, $t_{(9)}=0.98, p=0.35$; Fig. $3 D$ ), supporting the specificity of kainate-induced IEG expression as a measure of synaptic integration and suggesting that new maturation can only be rapidly accelerated after they have reached a certain level of maturity.
Acute

A

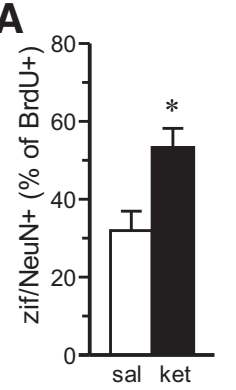

B

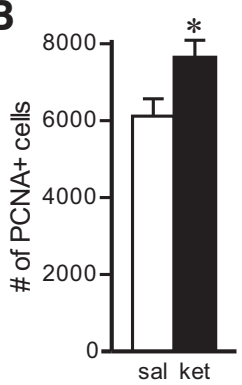

C

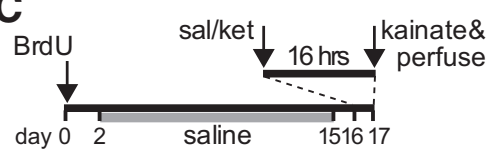

Younger Cells

D
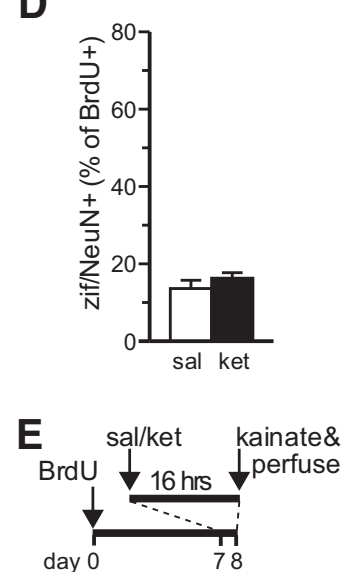

Very Rapid
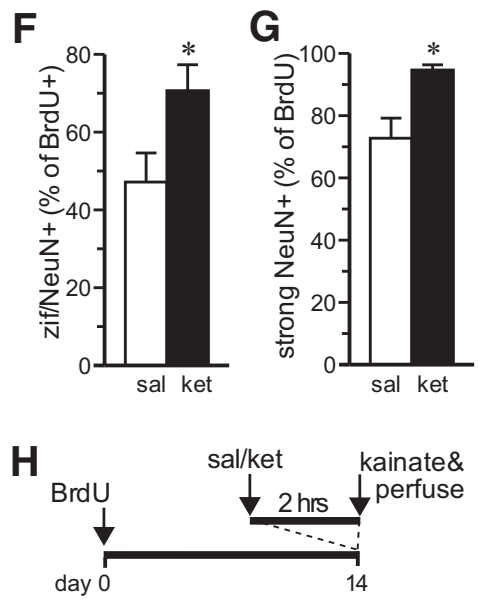

Figure 3. Rapid effects of ketamine on granule cell maturation and proliferation. $\boldsymbol{A}$, S-ketamine (ket) increased the proportion of 16 -d-old $\mathrm{BrdU}^{+}$cells colabeled with NeuN and zif268 (zif) $16 \mathrm{~h}$ later, relative to saline-treated controls (sal) $\left(* t\right.$ test, $t_{(4)}=3.065, p$ $=0.0375$ ). All bars represent mean \pm SEM. $\boldsymbol{B}$, S-ketamine increased the number of PCNA ${ }^{+}$(dividing) cells in the subgranular zone $16 \mathrm{~h}$ later $\left(* t\right.$ test, $\left.t_{(10)}=2.42, p=0.0359\right)$. $C$, Animal treatment time course for short-term effects; ketamine injection was $10 \mathrm{mg} / \mathrm{kg}$, i.p., in each experiment. $\boldsymbol{D}$, The maturation effect was not seen in 7 -d-old cells ( $t$ test, $t_{(9)}=0.98, p=0.35$ ). $\boldsymbol{E}$, Animal treatment time course for short-term effects in young cells. $\boldsymbol{F}, \boldsymbol{G}$, Increased zif/NeuN coexpression and strong NeuN expression were seen in 14-d-old cells within $2 \mathrm{~h}$ of ketamine treatment (zif: $* t$ test, $t_{(9)}=2.33, p=0.0450$; strong NeuN: $* t$ test, $t_{(9)}=3.55, p=0.0062$ ). $\boldsymbol{H}$, Animal treatment time course for very rapid effects on maturation. 
A

Daily ketamine $x 14$ days

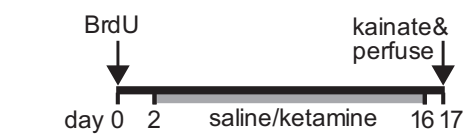

B

Daily ketamine $\mathrm{x} 21$ days

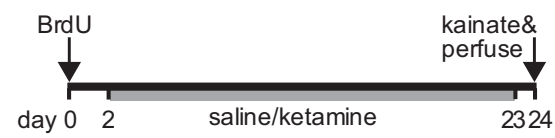

C

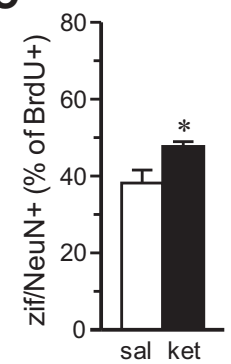

D

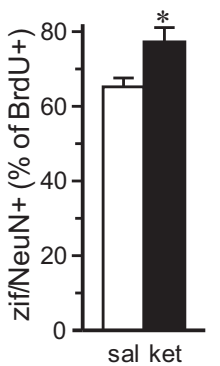

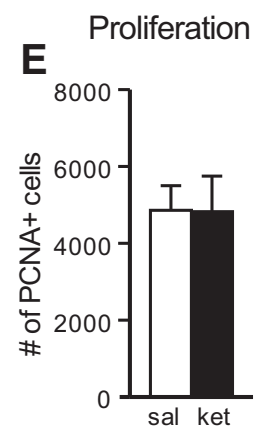

F

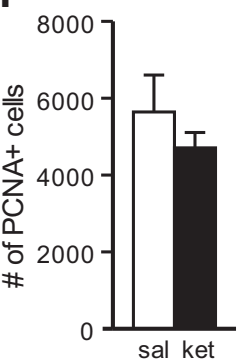

Survival

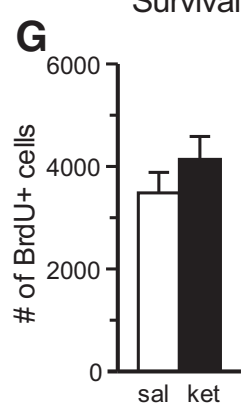

H

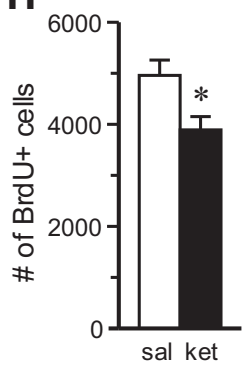

Figure 4. Effects of long-term ketamine treatment. $\boldsymbol{A}, \boldsymbol{B}$, Animal treatment time courses; all ketamine injections were $10 \mathrm{mg} / \mathrm{kg}$, i.p. $\boldsymbol{C}, \boldsymbol{D}$, Long-term daily ketamine treatment for $14 \mathrm{~d}(\boldsymbol{C})$ or $21 \mathrm{~d}(\boldsymbol{D})$ increased the proportion of zif/NeuN ${ }^{+} \mathrm{BrdU}^{+} \mathrm{granule}$ cells $(* 14 \mathrm{~d}$ : $t$ test, $t_{(9)}=3.20, p=0.0108 ; * 21 \mathrm{~d}: t$ test, $\left.t_{(11)}=2.773, p=0.0181\right)$. $\boldsymbol{E}, \boldsymbol{F}, \mathrm{S}$-ketamine had no effect on cell proliferation when administered daily for 14 or $21 \mathrm{~d}\left(14 \mathrm{~d}: t_{(10)}=0.035, p=0.973 ; 21 \mathrm{~d}: t_{(9)}=0.955, p=0.365\right)$. $\mathbf{G}, \boldsymbol{H}$, BrdU ${ }^{+}$cell survival was unaffected by $14 \mathrm{~d}$ of daily treatment with S-ketamine $\left(t\right.$ test, $\left.t_{(10)}=1.03, p=0.33\right)$ but was decreased after $21 \mathrm{~d}\left(* t\right.$ test, $\left.t_{(12)}=2.71, p=0.0191\right)$. All bars represent the mean $\pm \operatorname{SEM}(n=6-7$ per group).

Behavioral effects of ketamine have been observed within $2 \mathrm{~h}$ of ketamine administration (Fig. 1; Garcia et al., 2008; Engin et al., 2009; Li et al., 2010), so functional maturation of 14-d-old granule cells was assessed at this very short time point. After $2 \mathrm{~h}$, ketamine increased the proportion of 14 -d-old cells expressing zif268 by $50 \%$ compared with saline ( $t$ test, $t_{(9)}=2.33, p=0.0450$; Fig. $3 F$ ). Ketamine also significantly increased the proportion of $\mathrm{BrdU}^{+}$cells strongly immunoreactive for NeuN ( $t$ test, $t_{(9)}=3.55, p=0.0062$; Fig. 3G), another measure of neuronal maturity (Snyder et al., 2009b). Together, these data demonstrate that a low dose of ketamine very rapidly induces the maturation of young granule cells.

\section{Long-term daily ketamine treatment does not enhance single-injection effects}

Several studies have examined the behavioral effects of long-term daily ketamine treatment (Browne and Lucki, 2013). To determine the effects of long-term treatment with ketamine on neurogenesis, animals received ketamine daily (10 mg/kg, i.p.) for 15 or $22 \mathrm{~d}$, with kainate injection and perfusion $16 \mathrm{~h}$ after the last ketamine injection (Fig. 4A,B). Long-term ketamine significantly increased the proportion of BrdU-NeuN-zif268 ${ }^{+}$cells compared with the saline-treated group at both time points (14 d: $t$ test, $t_{(9)}=3.20, p=0.0108 ; 21 \mathrm{~d}: t$ test, $t_{(11)}$ $=2.773, p=0.0181$; Fig. $4 C, D)$. These increases, however, were approximately half as large as those seen with short-term treatment. PCNA cell counting showed no effect of long-term ketamine treatment after 14 or 21 d (14 $\mathrm{d}: t_{(10)}=0.035, p=0.973 ; 21 \mathrm{~d}: t_{(9)}=0.955, p=0.365$; Fig. $4 E, F)$.

The effects of ketamine on the survival of new granule cells was examined after long-term treatment by counting BrdU-labeled cells. To isolate the effects on survival from possible proliferation effects (Dayer et al., 2003), rats were given BrdU $2 \mathrm{~d}$ before ketamine treatment began. Long-term treatment with ketamine for $14 \mathrm{~d}$ had no effect on the number of surviving $\mathrm{BrdU}^{+}$cells located in the granule cell layer ( $t$ test, $t_{(10)}=1.03, p=0.33$; Fig. $4 G$ ), which is consistent with the lack of effect of the NMDA receptor antagonist 3-(2-carboxypiperazin-4-yl)propyl-1-phosphonic acid (CPP) on the survival of young granule cells observed previously in mice (Tashiro et al., 2006). Interestingly, $21 \mathrm{~d}$ of ketamine treatment decreased new granule cell survival ( $t$ test, $t_{(12)}=$ $2.71, p=0.0191$; Fig. $4 H$ ), producing the only negative effect of ketamine on neurogenesis observed in the study.

\section{Prolonged effects in a depression model}

To assess the duration of the effects of a single injection of ketamine, maturation and proliferation were examined $32 \mathrm{~d}$ after a single injection of ketamine (10 mg/kg, i.p) or saline. Ketamine effects were tested in control conditions and in a depressive-like state (Sterner and Kalynchuk, 2010) induced by long-term CORT treatment (Fig. 5C). CORT had no effect on zif268 expression, suggesting that maturation is unaffected by excess glucocorticoids (Fig. 5A). Ketamine, however, significantly increased the proportion of 16-d-old cells expressing zif 268 by $45 \%$ in both CORT-treated and untreated rats (main effect of CORT: $F_{(1,17)}=0.00, p=0.996 ; *$ main effect of 


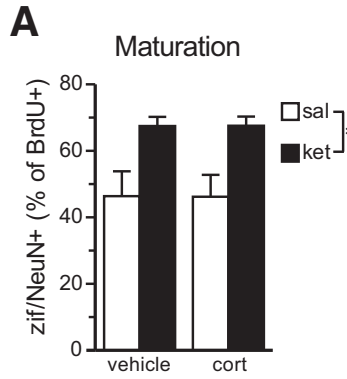

C
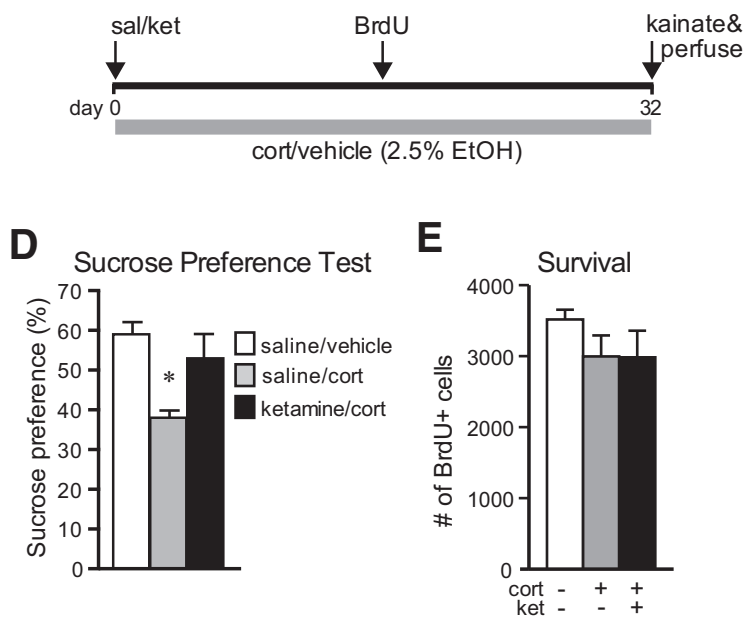

$\mathbf{F}$

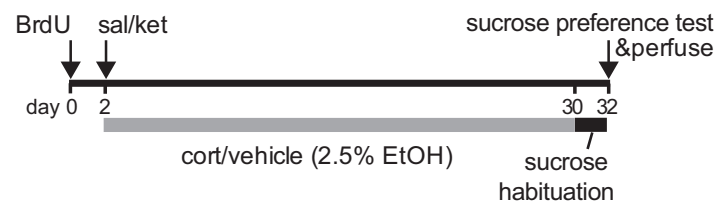

Figure 5. Sustained effects of S-ketamine in a depression model. $\boldsymbol{A}$, Ketamine given $32 \mathrm{~d}$ earlier increased zif/NeuN expression in 16-d-old cells regardless of long-term corticosterone exposure (main effect of CORT: $F_{(1,17)}=0.00, p=0.996$; $*$ main effect of ketamine: $F_{(1,17)}=14.99, p=0.0017$; CORT $\times$ ketamine interaction: $F_{(1,17)}=0.0005, p=0.9821$ by two-way ANOVA). B, S-ketamine increased the number of $\mathrm{PCNA}^{+}$cells 32 $d$ later and prevented the inhibition of proliferation by long-term corticosterone treatment $\left(*\right.$ main effect of ketamine: $F_{(1,23)}=$ 7.44, $p=0.013$; *main effect of CORT: $F_{(1,23)}=8.35, p=0.009$; CORT $\times$ ketamine interaction: $F_{(1,23)}=0.00, p=0.988$ by two-way ANOVA). $\boldsymbol{C}$, Animal treatment time course for maturation and proliferation effects. $\boldsymbol{D}$, A single S-ketamine injection prior to long-term CORT treatment prevented a decrease in sucrose preference (one-way ANOVA, $F_{(2,15)}=6.98, p=0.0072$; $* p<0.05$ vs saline in post hoc test). Values represent the mean \pm SEM ( $n=4-6$ per group). $\boldsymbol{E}$, Neither long-term exposure to CORT nor short-term ketamine exposure prior to CORT significantly altered new cell survival $\left(F_{(2,15)}=1.12, p=0.35\right.$ by one-way ANOVA). Values represent the mean $\pm \operatorname{SEM}(n=6-7$ per group. $\boldsymbol{F}$, Animal treatment time course for sucrose preference and survival effects.

ketamine: $F_{(1,17)}=14.99, p=0.0017$; CORT $\times$ ketamine interaction: $F_{(1,17)}=0.0005, p=0.982$ by two-way ANOVA), indicating that ketamine continues to accelerate neuronal mat- uration for several weeks, even in neurons born long after short-term ketamine treatment.

A single ketamine injection increased cell proliferation $32 \mathrm{~d}$ later (main effect of ketamine: $F_{(1,23)}=7.44, p=$ 0.013 ; Fig. $5 B, C)$. This finding extends a previous report that the NMDA receptor antagonist CGP43487 increases cell proliferation for at least $7 \mathrm{~d}$ (Nacher et al., 2001), but contrasts with a recent study showing no effect of ketamine on cell proliferation or $\mathrm{DCX}^{+}$cells $29 \mathrm{~d}$ after ketamine injection (Brachman et al., 2015), suggesting either a species difference or decreased efficacy of higher ketamine doses. Long-term exposure to corticosterone decreased the number of $\mathrm{PCNA}^{+}$cells by $33 \%$ (main effect of CORT: $F_{(1,23)}=8.35, p=0.009$; Fig. $5 B$ ), as expected based on previous studies (Wong and Herbert, 2005; David et al., 2009). CORT and ketamine had independent, additive effects that, when combined, resulted in a proliferation rate very close to the control level (CORT $\times$ ketamine interaction: $F_{(1,23)}=0.00, p=0.988$ by two-way ANOVA; Fig. 5B). A previous study found interactive effects, suggesting that NMDA receptor activation acts downstream of corticosterone at short-term time points (Cameron et al., 1998). The results observed here suggest that the sustained effects of ketamine, after the drug itself is out of the system, may not directly involve NMDA receptors.

To determine the effects of ketamine on anhedonia and survival, the experiment was repeated, administering BrdU prior to treatment and testing for sucrose preference (Fig. 5F), a model of anhedonia (David et al., 2009; Sterner and Kalynchuk, 2010). Rats treated with corticosterone for 28 d showed a $30 \%$ decrease in preference for sucrose compared with saline/vehicle-treated animals (Fig. $5 D$; for review, see Gourley et al., 2009; Sterner and Kalynchuk, 2010). This effect was reversed by ketamine (10 mg/kg, i.p.) given $32 \mathrm{~d}$ before testing (one-way ANOVA, $F_{(2,15)}=6.98, p=0.0072 ; p=0.0405$ vs saline/ CORT in post hoc test; Fig. $5 D$ ), a change that is unlikely to have been produced by nonspecific changes in thirst or hunger, because body weights and the total volume consumed during the $1 \mathrm{~h}$ test $(\sim 30 \mathrm{ml})$ showed no significant group differences ( $p=0.61$ and $p=0.22$, respectively). This experiment demonstrates sustained antidepressant activity of a single dose of ketamine in a model of depression that requires long-term treatment for efficacy of classic antidepressants (Sterner and Kalynchuk, 2010). These results are consistent with recently observed ketamine effects on NSF in a similar paradigm (Brachman et al., 2015).

No statistically significant effects of either CORT or ketamine on $\mathrm{BrdU}^{+}$cell survival were observed $\left(F_{(2,15)}=\right.$ $1.12, p=0.35$ by one-way ANOVA; Fig. $5 E$ ). The data suggest a possible inhibitory effect of corticosterone on survival but provide no hint of any effect of ketamine.

\section{New neurons are not required for behavioral effects of ketamine on neophagia}

To investigate whether rapid changes in the maturation of young neurons are causally related to rapid antidepressant-like effects in rats, we tested the behavioral 
A

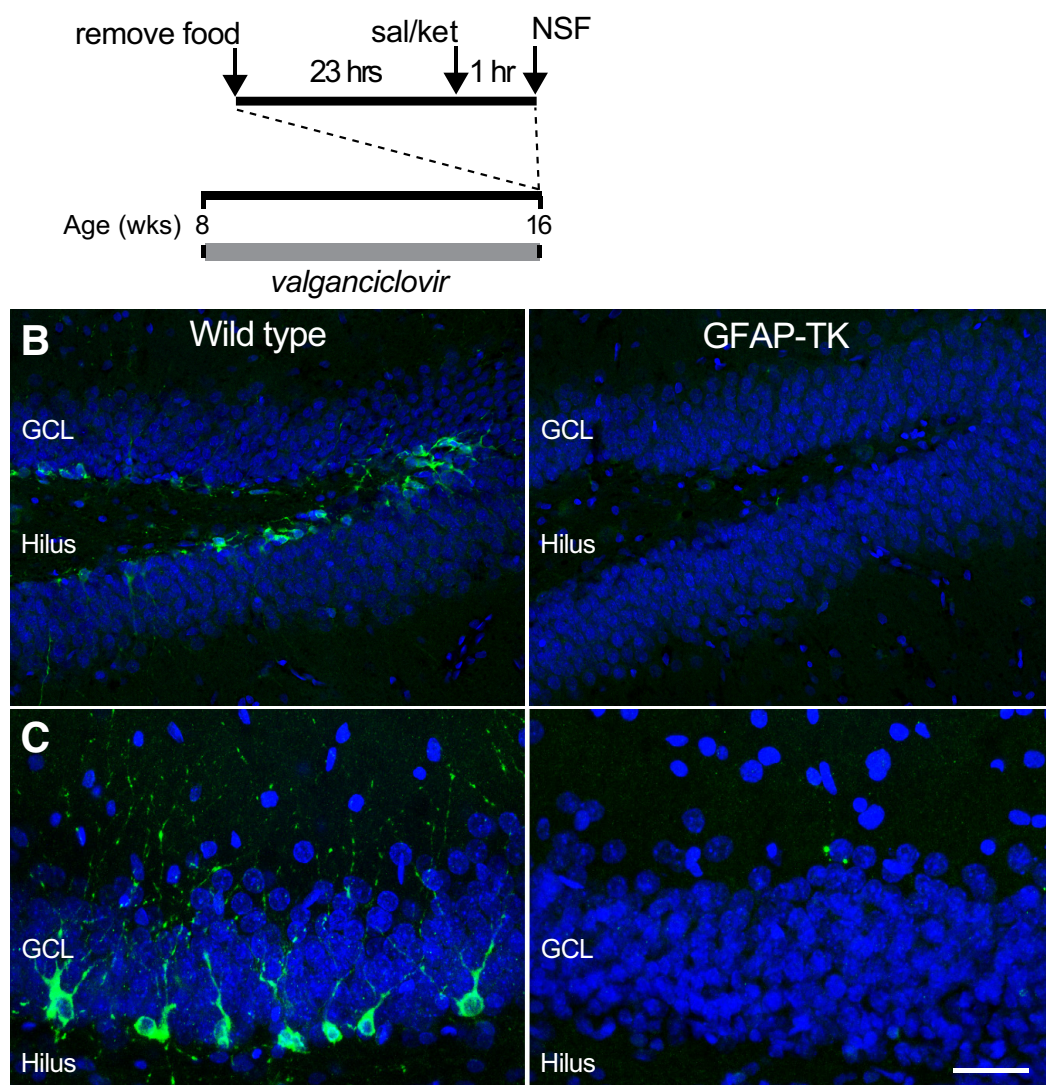

D

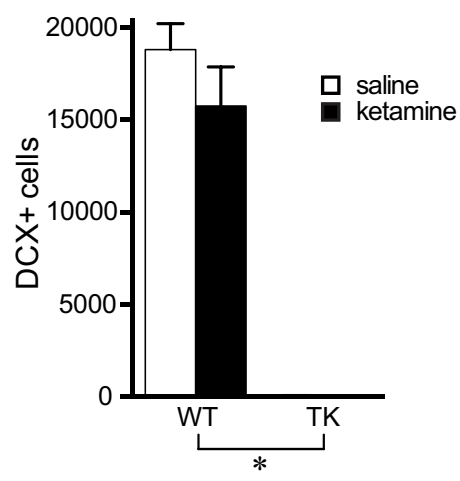

E

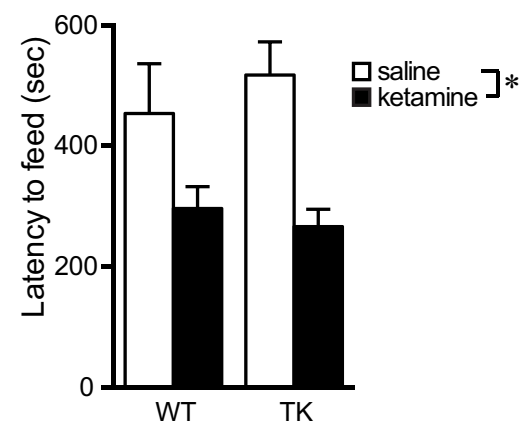

Figure 6. Neurogenesis is not required for the S-ketamine effect on novelty-suppressed feeding. $\boldsymbol{A}$, Animal treatment time course showing valganciclovir to inhibit neurogenesis, the injection of saline (sal) or ketamine (ket; $10 \mathrm{mg} / \mathrm{kg}$ ), and NSF testing. $\boldsymbol{B}$, Photographs show DCX-expressing young granule neurons (green) in the dentate gyrus of valganciclovir (VGCV)-treated wild-type rats (WT), but not in GFAP-TK (TK) rats. Blue counterstain shows cell nuclei. $\boldsymbol{C}$, Higher magnification of granule cell layer showing DCX staining. $\boldsymbol{D}$, Quantification shows near-complete absence of $\mathrm{DCX}^{+}$new neurons in GFAP-TK rats and no effect of short-term S-ketamine treatment on $\mathrm{DCX}^{+}$cell number. $\left(*\right.$ main effect of genotype: $F_{(1,20)}=183.6, p<0.0001$; main effect of ketamine: $F_{(1,20)}$ $=1.471, p=0.2392$; genotype $\times$ ketamine interaction: $F_{(1,20)}=1.418, p=0.2477$, all by two-way ANOVA) $\boldsymbol{E}$, In the NSF test, the latency to eat in a novel arena was decreased by S-ketamine in both wild-type and GFAP-TK rats (*main effect of genotype: $F_{(1,20)}$ $=0.2827, p=0.6008$; main effect of ketamine: $F_{(1,20)}=13.24, p=0.0016$; genotype $\times$ ketamine interaction: $F_{(1,20)}=0.3756, p=$ 0.5469 , all by two-way ANOVA). All bars represent mean \pm SEM.

effects of S-ketamine on NSF in rats lacking adult neurogenesis (Fig. 6A). This test was chosen because we and others have seen an antidepressant effect of ketamine in this test and because neurogenesis-dependent effects of fluoxetine have been found in this test (Santarelli et al., 2003; David et al., 2009). After 8 weeks of valganciclovir treatment, which virtually eliminated new neurons in the dentate gyrus of GFAP-TK rats (Fig. 6B), NSF behavior 
was tested in GFAP-TK rats and wild-type littermate controls. Injection of $10 \mathrm{mg} / \mathrm{kg}$ ketamine $1 \mathrm{~h}$ prior to testing significantly reduced the latency to feed in the novel environment (main effect of treatment in two-way ANOVA: $F_{(1,22)}=13.47, p=0.002$; Fig. $\left.6 C\right)$, as seen in our initial experiment (Fig. 1A). There was no main effect of genotype or treatment $\times$ genotype interaction (main effect of genotype: $F_{(1,22)}=0.09, p=0.767$; treatment $\times$ genotype interaction: $F_{(1,22)}=0.71, p=0.411$ by two-way ANOVA), indicating that new neurons are not required for the behavioral effects of S-ketamine in this test. Home cage consumption was not measured in this experiment, but previous studies in rats and mice have found no effect of short-term ketamine treatment on this measure (Autry et al., 2011; Li et al., 2011; lijima et al., 2012; Gideons et al., 2014; Nosyreva et al., 2014). Neurogenesisdependent effects on sucrose preference and forced swim behavior at baseline, in the absence of ketamine, prevented testing of the requirement for neurogenesis in the antidepressant effects of ketamine in these tests (Snyder et al., 2011).

\section{Discussion}

The present findings demonstrate that S-ketamine has both rapid and sustained effects on adult neurogenesis in the dentate gyrus. A single injection of ketamine increased the functional maturation of young neurons within hours and continued to accelerate maturation for at least 4 weeks. An increase in cell proliferation was also observed shortly after ketamine treatment and was sustained for at least 4 weeks. Long-term daily treatment with ketamine had more limited effects and had a small but significant negative effect on new neuron survival. The rapid and prolonged cellular effects matched the time course of behavioral effects in the NSF test, the FST, and the sucrose preference test. However, direct testing of the relationship between neurogenesis and behavioral effects on neophagia showed that new neurons were not required for a ketamine-induced decrease in this depressive-like behavior.

Accelerated maturation of adult-born neurons has previously been observed, but only after treatments lasting $\geq 1$ weeks. Treatment of mice with fluoxetine for $28 \mathrm{~d}$ increases newborn neuron dendritic length, while $5 \mathrm{~d}$ of treatment does not (Wang et al., 2008). Agomelatine, a melatonergic receptor agonist and $5-\mathrm{HT}_{2 \mathrm{C}}$ receptor antagonist, accelerates NeuN expression in granule cells after 8 d (Soumier et al., 2009). A nonpharmacologic treatment, exercise, increases the proportion of mature young neurons after $21 \mathrm{~d}$, but not after $14 \mathrm{~d}$ (Snyder et al., 2009a). The current study shows that similar changes in maturation can be induced by ketamine within only $2 \mathrm{~h}$. Many studies have demonstrated the formation of new synapses in the adult brain within days (Woolley and McEwen, 1992; Holtmaat and Svoboda, 2009), but the effects of ketamine on circuit formation are surprisingly fast, even by this standard. However, in vitro studies have demonstrated that dendritic spines on neocortical pyramidal neurons can form de novo in response to glutamate within minutes (Kwon and Sabatini, 2011; Okabe, 2013).
Ketamine acts at NMDA receptors, which are found throughout the brain. Our experiments could not determine whether the key NMDA receptors are those on the new neurons themselves or whether the effect is indirect. Studies using specific antagonists suggest that the effects of ketamine on synapse formation and depressivelike behavior are mediated through the NMDA receptors containing the NR2B subunit (Maeng et al., 2008; Li et al., 2010). NR2B-containing NMDA receptors, generally thought of as a developmental form of the NMDA receptor, are expressed on young granule cells and are required for a form of plasticity produced exclusively by young neurons (Snyder et al., 2001). Therefore, it is reasonable to suspect that the effects of ketamine on maturing granule cells occur directly through NR2B-containing NMDA receptors on these young neurons. Deletion of the NR1 subunit of NMDA receptors from young neurons decreases their survival in a cell-specific manner (Tashiro et al., 2006), supporting a direct role for NMDA receptors on the young neurons. The decrease in new neuron survival seen following $21 \mathrm{~d}$ of treatment with ketamine is consistent with the genetic ablation effects, though the relatively small effects seen with ketamine treatment suggest that survival effects of transient blockade are small and may be offset by increased cell proliferation.

Because ketamine acts as an antagonist, blocking NMDA receptors, the current findings suggest that endogenous activation of NMDA receptors normally slows the incorporation of new neurons into functional circuits. Neuronal activation is generally regarded as being an important positive modulator of neuronal maturation, so the enhancement of maturation by NMDA receptor blockade is somewhat counterintuitive. However, genetic ablation of NMDA receptors in developing CA1 pyramidal cells increases the number of functional synapses detected by slice physiology (Adesnik et al., 2008), which is counter to expectations but is consistent with our results. Developing neurons, including adult-born granule neurons (Chancey et al., 2013), have many silent synapses containing NMDA receptors, but no AMPA receptors. According to the model developed by Adesnik et al. (2008), low-level stimulation of these NMDA receptors inhibits AMPA receptor trafficking to the postsynaptic density. Strong activation of NMDA receptors normally overcomes this inhibition at some point during development, but the deletion of NMDA receptors, or perhaps in our case pharmacological blockade of the NMDA receptors, disinhibits AMPA receptor trafficking and results in greater numbers of AMPA receptor-containing functional synapses. This AMPA receptor trafficking and the stabilization of synapses occurs within minutes (Groc et al., 2006). This model is supported by findings that AMPA receptor activation is required for the antidepressant effects of ketamine (Maeng et al., 2008; Li et al., 2010; Autry et al., 2011; Koike et al., 2011). BDNF, which is upregulated by ketamine and has been suggested as a mediator of its antidepressant effects (Garcia et al., 2008; Duman, 2014), also increases CA1 pyramidal cell dendritic spine size, an indicator of synapse maturity, within 10 min (Hale et al., 2011). 
The finding that ketamine decreases feeding latency in the novelty-suppressed feeding task in adult rats lacking adult neurogenesis indicates that new neurons are not required for the antidepressant-like effects of ketamine, at least in this task. No rodent model of depressive-like behavior is clearly predictive of efficacy or the mechanism of action in humans (Nestler and Hyman, 2010; Fernando and Robbins, 2011; Hyman, 2012), so it is possible that neurogenesis could play a role in the antidepressant activity of ketamine in humans. However, NSF may be the best available test for assessing ketamine effects on depressive-like behavior in rodents for several reasons. First, behavioral changes in NSF faithfully model the time course of antidepressant effects in humans, requiring long-term treatment with SSRIs but only short-term treatment with ketamine. In addition, SSRI effects on NSF behavior, in contrast to those of ketamine, do require new neurons in mice (Santarelli et al., 2003), demonstrating a clear distinction from the ketamine effects on this test. This difference suggests that ketamine and SSRIs act through a different mechanism, not just at the level of receptors and neurotransmitter systems, but also at the level of neuronal populations. These findings further suggest that changes in adult neurogenesis are not the final common pathway for all antidepressant effects on rodent behavior and may not be important for the therapeutic effects of ketamine in humans. The effects of ketamine on behavior can be blocked with drug infusions into the prefrontal cortex (Li et al., 2010), suggesting that this brain region does play a role in antidepressant effects. Changes in AMPA receptors, signaling molecules, and dendritic spines have been observed in the prefrontal cortex $24 \mathrm{~h}$ after ketamine treatment (Browne and Lucki, 2013; Duman, 2014) but have not been described at earlier time points. Nonetheless, very rapid effects on synapse maturation, like those observed in the current study, may also occur in presumably mature neurons in the prefrontal cortex and could provide a mechanism for the behavioral effects. It may be difficult to capture these very rapid changes in mature neurons, where only a subset of spines is normally silent or otherwise immature and able to be modified.

Although ketamine does not appear to act through new neurons to produce its antidepressant effects in the NSF test, albeit with the caveats discussed above, its proneurogenic effects should be considered a side effect of this therapeutic treatment. The sustained effects, including increased cell proliferation and maturation for at least 4 weeks after a single treatment, may be the most important effects to consider in this context. Whether this increase in new neurons and the acceleration of their maturation would be expected to have positive or negative effects on mental health is not yet clear. Nor is it apparent whether the effects on adult neurogenesis are important for the sustained behavioral effects of ketamine, which was not directly tested in this study. However, the rapid effects of ketamine on new neurons may be valuable both for understanding the normal maturation of adult-born neurons and for studying the synaptic effects of ketamine that may occur more globally including in neurons responsible for its antidepressant effects.

\section{References}

Abdallah CG, Averill LA, Krystal JH (2015) Ketamine as a promising prototype for a new generation of rapid-acting antidepressants. Ann N Y Acad Sci 1344:66-77. CrossRef Medline

Adesnik H, Li G, During MJ, Pleasure SJ, Nicoll RA (2008) NMDA receptors inhibit synapse unsilencing during brain development. Proc Natl Acad Sci U S A 105:5597-5602. CrossRef Medline

Autry AE, Adachi M, Nosyreva E, Na ES, Los MF, Cheng P-F, Kavalali ET, Monteggia LM (2011) NMDA receptor blockade at rest triggers rapid behavioural antidepressant responses. Nature 475:91-95. CrossRef Medline

Bodnoff SR, Suranyi-Cadotte B, Aitken DH, Quirion R, Meaney MJ (1988) The effects of chronic antidepressant treatment in an animal model of anxiety. Psychopharmacology (Berl) 95:298-302. Medline

Brachman RA, McGowan JC, Perusini JN, Lim SC, Pham TH, Faye C, Gardier AM, Mendez-David I, David DJ, Hen R, Denny CA (2015) Ketamine as a prophylactic against stress-induced depressive-like behavior. Biol Psychiatry. Advance online publication. Retrieved March 23, 2016. CrossRef

Browne CA, Lucki I (2013) Antidepressant effects of ketamine: mechanisms underlying fast-acting novel antidepressants. Front Pharmacol 4:161. CrossRef Medline

Cameron HA, McEwen BS, Gould E (1995) Regulation of adult neurogenesis by excitatory input and NMDA receptor activation in the dentate gyrus. J Neurosci 15:4687-4692. Medline

Cameron HA, Tanapat P, Gould E (1998) Adrenal steroids and $\mathrm{N}$-methyl-D-aspartate receptor activation regulate neurogenesis in the dentate gyrus of adult rats through a common pathway. Neuroscience 82:349-354. Medline

Carrier N, Kabbaj M (2013) Sex differences in the antidepressant-like effects of ketamine. Neuropharmacology 70:27-34. CrossRef Medline

Chancey JH, Adlaf EW, Sapp MC, Pugh PC, Wadiche Jl, OverstreetWadiche LS (2013) GABA depolarization is required for experience-dependent synapse unsilencing in adult-born neurons. J Neurosci 33:6614-6622. CrossRef Medline

Cryan JF, Valentino RJ, Lucki I (2005) Assessing substrates underlying the behavioral effects of antidepressants using the modified rat forced swimming test. Neurosci Biobehav Rev 29:547-569. CrossRef Medline

David DJ, Samuels BA, Rainer Q, Wang J-W, Marsteller D, Mendez I, Drew M, Craig DA, Guiard BP, Guilloux J-P, Artymyshyn RP, Gardier AM, Gerald C, Antonijevic IA, Leonardo ED, Hen R (2009) Neurogenesis-dependent and -independent effects of fluoxetine in an animal model of anxiety/depression. Neuron 62:479-493. CrossRef Medline

Dayer AG, Ford AA, Cleaver KM, Yassaee M, Cameron HA (2003) Short-term and long-term survival of new neurons in the rat dentate gyrus. J Comp Neurol 460:563-572. CrossRef Medline

Duman RS (2004) Depression: a case of neuronal life and death? Biol Psychiatry 56:140-145. CrossRef Medline

Duman RS (2014) Neurobiology of stress, depression, and rapid acting antidepressants: remodeling synaptic connections. Depress Anxiety 31:291-296. CrossRef

Duman RS, Malberg J, Nakagawa S (2001) Regulation of adult neurogenesis by psychotropic drugs and stress. J Pharmacol Exp Ther 299:401-407. Medline

Engin E, Treit D, Dickson C (2009) Anxiolytic- and antidepressant-like properties of ketamine in behavioral and neurophysiological animal models. Neuroscience 161:359-369.

Fernando ABP, Robbins TW (2011) Animal models of neuropsychiatric disorders. Annu Rev Clin Psychol 7:39-61. CrossRef Medline

Garcia LSB, Comim CM, Valvassori SS, Réus GZ, Barbosa LM, Andreazza AC, Stertz L, Fries GR, Gavioli EC, Kapczinski F, Quevedo J (2008) Acute administration of ketamine induces 
antidepressant-like effects in the forced swimming test and increases BDNF levels in the rat hippocampus. Prog Neuropsychopharmacol Biol Psychiatry 32:140-144. CrossRef

Gideons ES, Kavalali ET, Monteggia LM (2014) Mechanisms underlying differential effectiveness of memantine and ketamine in rapid antidepressant responses. Proc Natl Acad Sci U S A 111:86498654. CrossRef Medline

Gourley SL, Kedves AT, Olausson P, Taylor JR (2009) A history of corticosterone exposure regulates fear extinction and cortical NR2B, GluR2/3, and BDNF. Neuropsychopharmacology 34:707716. CrossRef Medline

Groc L, Gustafsson B, Hanse E (2006) AMPA signalling in nascent glutamatergic synapses: there and not there! Trends Neurosci 29:132-139. CrossRef Medline

Hale CF, Dietz KC, Varela JA, Wood CB, Zirlin BC, Leverich LS, Greene RW, Cowan CW (2011) Essential role for vav guanine nucleotide exchange factors in brain-derived neurotrophic factorinduced dendritic spine growth and synapse plasticity. J Neurosci 31:12426-12436. CrossRef Medline

Holtmaat A, Svoboda K (2009) Experience-dependent structural synaptic plasticity in the mammalian brain. Nat Rev Neurosci 10:647658. CrossRef Medline

Hunt MJ, Raynaud B, Garcia R (2006) Ketamine dose-dependently induces high-frequency oscillations in the nucleus accumbens in freely moving rats. Biol Psychiatry 60:1206-1214. CrossRef Medline

Hyman SE (2012) Revolution stalled. Sci Transl Med 4:155cm11. CrossRef Medline

ladarola ND, Niciu MJ, Richards EM, Vande Voort JL, Ballard ED, Lundin NB, Nugent AC, Machado-Vieira R, Zarate CA (2015) Ketamine and other $\mathrm{N}$-methyl-D-aspartate receptor antagonists in the treatment of depression: a perspective review. Ther Adv Chronic Dis 6:97-114. CrossRef Medline

lijima M, Fukumoto K, Chaki S (2012) Acute and sustained effects of a metabotropic glutamate 5 receptor antagonist in the noveltysuppressed feeding test. Behav Brain Res 235:287-292. CrossRef Medline

Jones MW, Errington ML, French PJ, Fine A, Bliss TV, Garel S, Charnay P, Bozon B, Laroche S, Davis S (2001) A requirement for the immediate early gene Zif268 in the expression of late LTP and long-term memories. Nat Neurosci 4:289-296. CrossRef Medline

Jungenitz T, Radic T, Jedlicka P, Schwarzacher SW (2014) Highfrequency stimulation induces gradual immediate early gene expression in maturing adult-generated hippocampal granule cells. Cereb Cortex 24:1845-1857.

Kavalali ET, Monteggia LM (2015) How does ketamine elicit a rapid antidepressant response? Curr Opin Pharmacol 20:35-39. CrossRef Medline

Koike H, lijima M, Chaki S (2011) Involvement of AMPA receptor in both the rapid and sustained antidepressant-like effects of ketamine in animal models of depression. Behav Brain Res 224:107111. CrossRef Medline

Kwon H-B, Sabatini BL (2011) Glutamate induces de novo growth of functional spines in developing cortex. Nature 474:100-104. CrossRef Medline

Li N, Lee B, Liu R-J, Banasr M, Dwyer JM, Iwata M, Li X-Y, Aghajanian G, Duman RS (2010) mTOR-dependent synapse formation underlies the rapid antidepressant effects of NMDA antagonists. Science 329:959-964. CrossRef

Li N, Liu R-J, Dwyer JM, Banasr M, Lee B, Son H, Li X-Y, Aghajanian G, Duman RS (2011) Glutamate N-methyl-D-aspartate receptor antagonists rapidly reverse behavioral and synaptic deficits caused by chronic stress exposure. Biol Psychiatry 69:754-761. CrossRef Medline

Maeng S, Zarate CA, Du J, Schloesser RJ, McCammon J, Chen G, Manji HK (2008) Cellular mechanisms underlying the antidepressant effects of ketamine: role of alpha-amino-3-hydroxy-5methylisoxazole-4-propionic acid receptors. Biol Psychiatry 63: 349-352. CrossRef Medline
Malberg JE, Eisch AJ, Nestler EJ, Duman RS (2000) Chronic antidepressant treatment increases neurogenesis in adult rat hippocampus. J Neurosci 20:9104-9110. Medline

Mathew SJ, Shah A, Lapidus K, Clark C, Jarun N, Ostermeyer B, Murrough JW (2012) Ketamine for treatment-resistant unipolar depression: current evidence. CNS Drugs 26:189-204. CrossRef Medline

Nacher J, McEwen BS (2006) The role of N-methyl-D-asparate receptors in neurogenesis. Hippocampus 16:267-270. CrossRef Medline

Nacher J, Rosell DR, Alonso-Llosa G, McEwen BS (2001) NMDA receptor antagonist treatment induces a long-lasting increase in the number of proliferating cells, PSA-NCAM-immunoreactive granule neurons and radial glia in the adult rat dentate gyrus. Eur J Neurosci 13:512-520. Medline

Nestler EJ, Hyman SE (2010) Animal models of neuropsychiatric disorders. Nat Neurosci 13:1161-1169. CrossRef Medline

Nosyreva E, Autry AE, Kavalali ET, Monteggia LM (2014) Age dependence of the rapid antidepressant and synaptic effects of acute NMDA receptor blockade. Front Mol Neurosci 7:94. CrossRef Medline

Okabe S (2013) Fluorescence imaging of synapse formation and remodeling. Microscopy (Oxf) 62:51-62. CrossRef Medline

Overstreet-Wadiche LS, Bromberg DA, Bensen AL, Westbrook GL (2006) Seizures accelerate functional integration of adultgenerated granule cells. J Neurosci 26:4095-4103. CrossRef

Piatti VC, Espósito MS, Schinder AF (2006) The timing of neuronal development in adult hippocampal neurogenesis. Neuroscientist 12:463-468. CrossRef Medline

Porsolt RD, Brossard G, Hautbois C, Roux S (2001) Rodent models of depression: forced swimming and tail suspension behavioral despair tests in rats and mice. Curr Protoc Neurosci Chapter8: Unit8.10A. CrossRef Medline

Sanacora G, Zarate CA, Krystal JH, Manji HK (2008) Targeting the glutamatergic system to develop novel, improved therapeutics for mood disorders. Nat Rev Drug Discov 7:426-437. CrossRef Medline

Santarelli L, Saxe M, Gross C, Surget A, Battaglia F, Dulawa S, Weisstaub N, Lee J, Duman R, Arancio O, Belzung C, Hen R (2003) Requirement of hippocampal neurogenesis for the behavioral effects of antidepressants. Science 301:805-809. CrossRef Medline

Skolnick P, Layer RT, Popik P, Nowak G, Paul IA, Trullas R (1996) Adaptation of $\mathrm{N}$-methyl-D-aspartate (NMDA) receptors following antidepressant treatment: implications for the pharmacotherapy of depression. Pharmacopsychiatry 29:23-26. CrossRef Medline

Skolnick P, Popik P, Trullas R (2009) Glutamate-based antidepressants: 20 years on. Trends Pharmacol Sci 30:563-569. CrossRef Medline

Snyder JS, Kee N, Wojtowicz JM (2001) Effects of adult neurogenesis on synaptic plasticity in the rat dentate gyrus. J Neurophysiol 85:2423-2431. Medline

Snyder JS, Glover LR, Sanzone KM, Kamhi JF, Cameron HA (2009a) The effects of exercise and stress on the survival and maturation of adult-generated granule cells. Hippocampus 19:898-906. CrossRef Medline

Snyder JS, Choe JS, Clifford MA, Jeurling SI, Hurley P, Brown A, Kamhi JF, Cameron HA (2009b) Adult-born hippocampal neurons are more numerous, faster maturing, and more involved in behavior in rats than in mice. J Neurosci 29:14484-14495. CrossRef Medline

Snyder JS, Soumier A, Brewer M, Pickel J, Cameron HA (2011) Adult hippocampal neurogenesis buffers stress responses and depressive behaviour. Nature 476:458-461. CrossRef Medline

Soumier A, Banasr M, Lortet S, Masmejean F, Bernard N, Kerkerian-LeGoff L, Gabriel C, Millan MJ, Mocaer E, Daszuta A (2009) Mechanisms contributing to the phase-dependent regulation of neurogenesis by the novel antidepressant, agomelatine, in the adult rat hippocampus. Neuropsychopharmacology 34:2390-2403. CrossRef Medline

Sterner EY, Kalynchuk LE (2010) Behavioral and neurobiological consequences of prolonged glucocorticoid exposure in rats: relevance to depression. Prog Neuropsychopharmacol Biol Psychiatry 34:777-790. CrossRef Medline 
Tashiro A, Sandler VM, Toni N, Zhao C, Gage FH (2006) NMDAreceptor-mediated, cell-specific integration of new neurons in adult dentate gyrus. Nature 442:929-933. CrossRef Medline

Wang J-W, David DJ, Monckton JE, Battaglia F, Hen R (2008) Chronic fluoxetine stimulates maturation and synaptic plasticity of adult-born hippocampal granule cells. J Neurosci 28:1374-1384. CrossRef Medline

Warner-Schmidt JL, Duman RS (2006) Hippocampal neurogenesis: opposing effects of stress and antidepressant treatment. Hippocampus 16:239-249. CrossRef Medline
Wilson C, Kercher M, Quinn B, Murphy A, Fiegel C, McLaurin A (2007) Effects of age and sex on ketamine-induced hyperactivity in rats. Physiol Behav 91:202-207. CrossRef Medline

Wong EYH, Herbert J (2005) Roles of mineralocorticoid and glucocorticoid receptors in the regulation of progenitor proliferation in the adult hippocampus. Eur J Neurosci 22:785-792. CrossRef Medline

Woolley CS, McEwen BS (1992) Estradiol mediates fluctuation in hippocampal synapse density during the estrous cycle in the adult rat. J Neurosci 12:2549-2554. Medline 